\title{
Evaluation of the role of neurosurgical procedures in the pathogenesis of secondary brain-stem haemorrhages ${ }^{1}$
}

\author{
GORDON K. KLINTWORTH \\ From the Department of Pathology, Duke University Medical Center, Durham, N.C., U.S.A.
}

During the experimental investigation of the pathogenesis of mesencephalic and pontine haemorrhages associated with supratentorial expanding lesions, it became apparent that removal of the intracranial mass during a particular period was often critical to their development and accentuated their severity (Klintworth, 1965). These observations raise the question whether alleviation of intracranial pressure under comparable circumstances predisposes to secondary brain-stem haemorrhages in man. This possibility is strengthened by certain clinicopathological studies which have revealed a high incidence of lumbar puncture, pneumoencephalography, ventriculography, or neurosurgical procedure in individuals manifesting secondary brainstem haemorrhages (van Gehuchten, 1937; Le Beau, 1943; Carrillo, 1950; Cannon, 1951; Poppen, Kendrick, and Hicks, 1962; Fields and Halpert, 1953; Cabieses, 1956).

The present study attempts to elucidate the role of neurosurgical procedures in the pathogenesis of these bulbar vascular lesions in man.

\section{MATERIALS AND METHODS}

A prospective and retrospective clinico-pathological investigation was performed on over 1,200 patients with supratentorial expanding lesions. The incidence and temporal relationship of neurosurgical procedures to secondary brain-stem haemorrhages was analysed. The data reviewed were obtained from the South African Institute of Medical Research, Johannesburg, South Africa, and the Duke University Medical Center and Durham Veterans Administration Hospital, Durham, North Carolina, U.S.A.

Discrete supratentorial lesions having a maximum diameter of less than $2 \mathrm{~cm}$. or a volume of less than $20 \mathrm{ml}$. were excluded from the review. Because of the difficulty in evaluating minor degrees of cerebral oedema objectively, this diagnosis was accepted only when the weight and gross appearance of the brain and the history were compatible with the diagnosis. When oedema was associated with another supratentorial condition, e.g., ${ }^{1}$ This work was supported by U.S.P.H.S. grant N.B. $-06805-01$. cerebral infarction, cerebral abscess, metastatic neoplasm, the lesion was classified according to the primary affection. Recent traumatic supratentorial expanding masses were excluded from the analysis, as haemorrhages in the brain-stem of such cases may have resulted from the initial trauma.

Surgically treated patients manifesting secondary brain-stem haemorrhages were classified according to the clinical manifestations at the time of surgery as follows:

\begin{tabular}{ll} 
Type & Manifestations \\
\hline I & $\begin{array}{l}\text { Absence of clinically manifest intracranial disease } \\
\text { Focal neurological symptoms and/or signs, such as } \\
\text { epilepsy, or hemiparesis, but no overt evidence of in- } \\
\text { creased intracranial pressure } \\
\text { Mild to moderate increased intracranial pressure with or } \\
\text { without focal manifestations. This group includes patients } \\
\text { with (1) lumbar spinal fluid pressures of 150-400 mm., } \\
\text { III }\end{array} \quad \begin{array}{l}\text { (2) mild papilloedema } \\
\text { fevere increased intracranial pressure with or without } \\
\text { (1) lumbar spinal fluid pressures of more than } 400 \text { mm., }\end{array}$ \\
V & $\begin{array}{l}\text { (2) severe papilloedema } \\
\text { Moribund with an obvious intracranial expanding lesion }\end{array}$
\end{tabular}

RESULTS

Secondary brain-stem haemorrhages were associated with a wide variety of supratentorial lesions which were either large focal masses or extensive diffuse lesions (Table I). Although over half of the subjects with secondary brain-stem haemorrhages did not experience any form of surgery, an impressive number did. A few of the latter survived postoperative periods of more than three weeks and surgery clearly had no bearing on the secondary brain-stem haemorrhages. Recent spontaneous haemorrhages were present within the tumour masses of all six patients with gliomas who manifested secondary brain-stem haemorrhages after postoperative survival periods of three months to four years. Two patients with surgically treated ruptured intracranial aneurysms died 25 and 29 days after surgery. Both had recent massive supratentorial haemorrhage and infarction secondary to second bleeds.

Most post-operative patients with secondary brain-stem haemorrhages who died within a week of 
TABLE I

SUMMARY OF SUPRATENTORIAL LESIONS ASSOCIATED WITH SECONDARY BRAIN-STEM HAEMORRHAGES

Neurosurgically Treated Cases with Secondary Brain-stem Haemorrhages

\begin{tabular}{|c|c|c|c|c|c|c|c|c|c|c|c|}
\hline \multirow[t]{2}{*}{ Supratentorial Lesion } & \multirow[t]{2}{*}{$\begin{array}{l}\text { Sample } \\
\text { Size }\end{array}$} & \multirow[t]{2}{*}{$\begin{array}{l}\text { Incidence of Secondary } \\
\text { Brain-stem Haemorrhages }\end{array}$} & \multicolumn{2}{|c|}{$\begin{array}{l}\text { Cases with Secondary } \\
\text { Brain-stem Haemorrhages }\end{array}$} & \multicolumn{5}{|c|}{$\begin{array}{l}\text { Pre-operative } \\
\text { Classification }\end{array}$} & \multicolumn{2}{|c|}{ Post-operative Ste } \\
\hline & & & $\begin{array}{l}\text { Without Neuro- } \\
\text { surgery }\end{array}$ & $\begin{array}{l}\text { With Neuro- } \\
\text { surgery }\end{array}$ & $I$ & $\boldsymbol{I I}$ & III & $I V$ & $\boldsymbol{V}$ & $\begin{array}{l}\text { Less than } \\
\text { l Week }\end{array}$ & $\begin{array}{l}\text { Greate } \\
3 \text { Wesik. }\end{array}$ \\
\hline Cerebral glioma & 165 & $42(25 \cdot 5 \%)$ & $6(14 \cdot 3 \%)$ & $36(85 \cdot 7 \%)$ & 0 & $\mathbf{0}$ & 8 & 19 & 9 & 30 & \\
\hline Metastatic tumour & 96 & $11(11 \cdot 5 \%)$ & $1(9 \cdot 1 \%)$ & $10(90 \cdot 9 \%)$ & $1^{2}$ & 0 & $\mathbf{0}$ & 3 & 6 & 10 & 4 \\
\hline Chromophobe adenoma & 18 & $3(16 \cdot 7 \%)$ & $1(33.3 \%)$ & $2(66 \cdot 7 \%)$ & $\mathbf{0}$ & $\mathbf{0}$ & 2 & $\mathbf{0}$ & 0 & 2 & \\
\hline Craniopharyngioma & 14 & $2(14 \cdot 3 \%)$ & $0(0 \%)$ & $2(100 \cdot 0 \%)$ & 0 & $\mathbf{0}$ & 1 & 1 & $\mathbf{0}$ & 2 & q \\
\hline Intracerebral haemorrhage & 168 & $53(31.5 \%)$ & $45(84.9 \%)$ & $8(15 \cdot 1 \%)$ & $\mathbf{0}$ & $\mathbf{0}$ & 0 & 2 & 6 & 8 & \\
\hline Cerebral infarction (recent) & 268 & $31(11.6 \%)$ & $21(67 \cdot 7 \%)$ & $10(32 \cdot 3 \%)$ & $\mathbf{0}$ & 2 & 4 & 2 & 2 & 10 & 2 \\
\hline Cerebral abscess & 84 & $6(7 \cdot 1 \%)$ & $1(16.7 \%)$ & $5(83 \cdot 3 \%)$ & 0 & 0 & 1 & 3 & $i$ & 5 & as \\
\hline Subdural haemorrhage & 101 & $22(21 \cdot 8 \%)$ & $14(63.6 \%)$ & $8(36.4 \%)$ & 0 & $\mathbf{0}$ & 0 & 2 & 6 & 8 & \\
\hline Miscellaneous haemorrhage and & & & & & 0 & 0 & $\mathbf{0}$ & 2 & 8 & 8 & \\
\hline infarct $^{1}$ & 328 & $35(10 \cdot 7 \%)$ & $25(71 \cdot 4 \%)$ & $10(28 \cdot 6 \%)$ & $1^{2}$ & 2 & 16 & 34 & 38 & 83 & \\
\hline Total cases & 1,242 & $205(16.5 \%)$ & $114(55.8 \%)$ & $91(44 \cdot 2 \%)$ & & & & & & & \\
\hline
\end{tabular}

${ }^{1}$ This group includes supratentorial haemorrhages which were situated at multiple sites as well as those associated with recent cerebral infarction. 'This patient underwent a frontal leucotomy for pain due to widespread malignancy. Surgery was complicated by haemorrhage into an unsuspected met: tumour in the frontal lobe.

surgery either underwent surgery for an intracranial lesion which was predominantly haemorrhagic or oedematous, or developed post-operative cerebral haemorrhage or oedema. In two cases the restoration of cerebral blood flow by carotid endarterectomy for carotid artery thrombosis was complicated by haemorrhage into the infarcted area.

Many patients with slowly expanding supratentorial lesions, such as cerebral gliomas or subdural haematomas and secondary brain-stem haemorrhages, did not manifest any overt increase in intracranial mass. An outstanding feature of such cases was the high incidence of craniectomy with relief of increased intracranial pressure by resection of tumour, evacuation of haematomas, lobectomy, subtemporal decompression, or ventricular drainage. These patients almost invariably underwent such procedures while comatose after manifesting a progressive increase in intracranial pressure and many were moribund before surgery. Characteristic of this group was the failure to regain consciousness following surgery and death ensuing, usually within the first 48 post-operative hours.

\section{DISCUSSION}

An objective evaluation of the role of neurosurgical procedures in the pathogenesis of secondary brainstem haemorrhages is extremely difficult, as the sample of case material is derived from post-mortem examination and is biased towards therapeutic failures rather than successes. Although it is clear that secondary brain-stem haemorrhages can occur in the absence of surgery, the high incidence of postoperative cases, particularly with slowly expanding supratentorial lesions, warrants consideration.
In the present investigation most secondary brainstem haemorrhages were associated with extensive supratentorial haemorrhage or oedema either alone or in association with a neoplasm, abscess, ono infarct. However, in some post-operative patient星 with relatively slowly expanding masses haemorro hage and oedema were inconspicuous. Subjects wit such supratentorial lesions invariably underwent relief of increased intracranial pressure, sometimes only with a terminal ventricular tap, after a prof gressive increase in intracranial pressure an generally when comatose and manifesting hypefơ tension and unilateral or bilateral fixed dilated $\delta$ pupils. Although caution generally must be exercised in extrapolating from experimental observations to clinical situations, the discovery that relief of intracranial pressure during a particular period in physiological decompensation predisposes to experimentally produced secondary brain-stem haemorrhages (Klintworth, 1965) suggests that some of the present data may represent a comparable situation in man. Such an explanation may account at least in part for the high incidence of neurosurgical procedures in patients with secondary brain-stem haemorrhages and for the well-established clinical observation that bilateral fixed dilated pupils generally indicates an ominous course in supratentorial expanding masses even with adequate surgery.

The pathogenesis of secondary brain-stem haemorrhages has yet to be fully established under controlled conditions, but available clinico-pathological and experimental data strongly suggest that a combination of a large supratentorial mass, a damaged brain-stem, as by displacement, and an active circulation through the brain-stem are essential to their occurrence (Klintworth, 1965, 1966). It is clear that 
cerebral blood flow decreases, that the cerebral circulation time increases, and that it may be impossible to demonstrate intracranial blood vessels by angiography in subjects with severe increased intracranial pressure (Kety, Shenkin, and Schmidt, 1948; Riishede and Ethelberg, 1953; Tönnis and Schiefer, 1954, 1959; Gänshirt and Tönnis, 1956; Greitz, 1956; Horwitz and Dunsmore, 1956; Woringer, Langs, Braun, and Baumgartner, 1956; Gänshirt, 1957; Gros, Vlahovitch, and Roilgen, 1959; Löfstedt and Von Reis, 1959; Pribram, 1961; Lecuire, de Rougemont, Descotes, and Jouvet, 1962; Troupp and Heiskanen, 1963; and Heiskanen, 1963). Supratentorial decompression presumably restores cerebral blood flow and initiates haemorrhages into the brain-stem only in those cases in which the vasculature of the brain-stem has been damaged as a result of mechanical shearing and/or anoxia.

Although Cushing (1902) did not make specific reference to secondary haemorrhages in the brainstem, it is of interest that he appreciated the danger of relieving increased intracranial pressure under circumstances similar to those outlined above. $\mathrm{He}$ stated: 'It must be remembered, however, that the sudden removal of pressure from the brain when the blood-pressure has been forced to considerable heights may be followed by paralysis instead of a release from the major compression symptoms. The occasion of this is readily brought out by postmortem examination, which, under such circumstances, oftentimes discloses a brain and medulla of a uniform cherry-red color, from the widespread extravasation of blood due to the multiple rupture of the minute blood vessels. The external supporting pressure of the high intracranial tension has been suddenly removed, leaving the internal or intravascular pressure too great for the strength of the vessel walls.'

\section{SUMMARY}

A prospective and retrospective clinico-pathological investigation was performed on over 1,200 patients with supratentorial expanding lesions. Most patients manifesting secondary brain-stem haemorrhages had extensive supratentorial haemorrhage or oedema either alone or in association with a neoplasm, abscess, or infarct. Although most secondary brainstem haemorrhages occurred in the absence of surgery, a large number of cases were post-operative. Secondary brain-stem haemorrhages were almost invariably associated with supratentorial expanding lesions in which there was either a relatively rapid increase in supratentorial mass due to haemorrhage or oedema, or increased intracranial pressure was partially or completely relieved while the patient was comatose with unilateral or bilateral fixed dilated pupils and manifesting hypertension. When viewed in the light of previous experimental data the latter cases suggest that alleviation of intracranial pressure under certain circumstances may predispose to secondary brain-stem haemorrhage in man.

\section{REFERENCES}

Cabieses, F. (1956). El tronco encefalico en las lesiones expansivas supratentoriales. Universidad Nacional Major de San Marcos Facultad de Medicina, Lima, Peru.

Cannon, B. W. (1951). Acute vascular lesions of the brain stem: a complication of supratentorial space-occupying lesions. Arch. Neurol. Psychiat. (Chic.), 66, 687-696.

Carrillo, R. (1950). Hernias cisternales. Arch. Neurocirug., 7, 498-590.

Cushing, H. (1902). Some experimental and clinical observations concerning states of increased intracranial tension. Amer. J. med. Sci., n.s., 124, 375-400.

Fields, W. S., and Halpert, B. (1953). Pontine hemorrhages in intracranial hypertension. Amer. J. Path., 29, 677-687.

Gänshirt, H., and Tönnis, W. (1956). Durchblutung und Sauerstoffverbrauch des Hirns bei intrakraniellen Tumoren. Dtsch. $Z$. Nervenheilk., 174, 305-330.

- (1957). Die Sauerstoffversorgung des Gehirns und ihre Störung bei der Liquordrucksteigerung und beim Hirnödem. Springer, Berlin.

van Gehuchten, P. (1937). Le mécanisme de la mort dans certains cas de tumeur cérébrale. Encéphale, 2, 113-127.

Greitz, T. (1956). A radiologic study of the brain circulation by rapid serial angiography of the carotid artery. Acta radiol. (Stockh.), suppl., 140, 1-123.

Gros, C., Vlahovitch, B., and Roilgen, A. (1959). Images angiographiques d'arrêt circulatoire encéphalique total dans les souffrances aigues du tronc cérébral. Neuro-chirurgie, 5, 113129.

Heiskanen, O. (1963). Cerebral circulatory arrest caused by acute increase of intracranial pressure: a clinical and roentgenological study of 25 cases. Acta neurol. scand., 40, suppl., 7.

Horwitz, N. H., and Dunsmore, R. H. (1956). Some factors influencing the non-visualization of the internal carotid artery by angiography. J. Neurosurg., 13, 155-164.

Kety, S. S., Shenkin, H. A., and Schmidt, C. F. (1948). The effects of increased intracranial pressure on cerebral circulatory functions in man. J. clin. Invest., 27, 493-499.

Klintworth, G. K. (1965). The pathogenesis of secondary brain-stem hemorrhages as studied in an experimental model. Amer. J. Path., 47, 525-536.

- (1966). The pathogenesis of brainstem vascular lesions secondary to supratentorial expanding masses. Proc. 5th int. Congr. Neuropath., pp. 38-40.

Le Beau, J. (1943). L'engagement du lobe temporal: étude de physiopathologic cérébrale. Un. méd. Can., 72, 761-771.

Lecuire, J., Rougemont, G. de, Descotes, J., and Jouvet, M. (1962). Données concernant les arréts circulatoires encéphaliques Neuro-chirurgie, 8, 158-167.

Löfstedt, S., and Von Reis, G. (1959). Diminution or obstruction of blood flow in the internal carotid artery. Opusc. med. (Stockh.), 4, 345-360.

Poppen, J. L., Kendrick, J. F., and Hicks, S. F. (1962). Brainstem hemorrhages secondary to supratentorial space-taking lesions. J. Neuropath. exp. Neurol., 11, 267-279.

Pribram, H. F. W. (1961). Angiographic appearance in acute intracranial hypertension. Neurology (Minneap.), 11, 10-21.

Riishede J., and Ethelberg, S. (1953). Angiographic changes in sudden and severe herniation of brain stem through tentorial incisure. Arch. Neurol. Psychiat. (Chic.), 70, 399-409.

Tönnis, W., and Shiefer, W. (1954). Die Bedeutung der Serienangiographie für die Artdiagnose der Hirngeschwülste. Fortschr. Röntgenstr., 81, 616-628.

(1959). Zirkulationsströrungen des Gehirns im Serienangiogramm, Springer, Berlin.

Troupp, H., and Heiskanen, O. (1963). Cerebral angiography in cases of extremely high intracranial pressure. Acta neurol. scand., 39, 213-223.

Woringer, E., Langs, A., Braun, J., and Baumgartner, J. (1956). Etude sério-angiographique de la dynamique circulatoire du cerveau. Acta radiol. (Stockh.), 46, 357-363. 